\title{
Quality of Work Life Program as A Humanistic Perspective on HRM
}

\author{
Verina H. Secapramana \\ Faculty of Psychology University of Surabaya \\ verina@staff.ubaya.ac.id
}

\begin{abstract}
Quality of Work Life as a contemporary perspective on HRM is related to meaningful, satisfying, and effective work environment that meets with the organizational and personal needs. Moreover, having quality of work life will lead to better well being of the workers and society. This 3 years long study was conducted at a steel company in East Java, Indonesia. The first year aimed to get base line data problems that arise in the organization using the concept of Quality of Work Life of the European Foundation for the Improvement of Living and Working Conditions (EWON, 2002), which has 5 dimension, i.e health and wellbeing, work and non-work life balance, job security, job satisfaction, and competency development. Focus group discussion and SWOT analysis was conducted based on these data to get an overview of the problems.
\end{abstract}

Several programs and systems were set up as an intervention of the existing problems in order to improve the Quality of Work Life, such as organizational development and change management, training of professionalism, stress management, leadership training, while the system set up were Employee Assistance Program, work load analysis, remuneration system, talent management, and career path.

With this action research design, these programs were expected to give benefit both to the management and the workers. It is expected that all of the efforts will have an impact on improving the quality of industrial relations, increasing employee productivity and performance, as well as improving the quality of life for all members of the organization.

Key words : Quality of Work Life program, humanistic perspectives, EWON, action research

\section{- Introduction}

The issue of improving the quality of working life is becoming increasingly important to establish a more conducive working environment for the members of the organization concerned. Zohurul Islam and Sununta Siengthai (2009) find that quality of work life has an effect on organizational performance. Studies from Kim, Pen and Joanne (2013); Venkatesh J, and Aarthy C (2013) conclude that the quality of working life built into an organization can make employees happier and form healthier cooperative relationships. Such working life conditions will contribute to improving work motivation. Kanten and Omer Sadullah (2012) found that quality of work life related to employee engagement.

Quality of work life is a feeling of satisfaction that employees have for their work, colleagues, and

\author{
Eko Nugroho \\ Faculty of Business and Economica University of Surabaya
}

organizations, which will lead to the growth and profitability of the organization (Heskett, Sasser, \& Schlesinger, 1997). A pleasant and conducive working environment will support and enhance job satisfaction, with rewards, a sense of security at work and a good opportunity to develop (Lau et a.1, 2001). Quality of work life is formed when the work environment is effective because of the fulfillment of the needs of the organization and personal needs. According to J.Richard and J.Lay (in Venkatesh \& Aarthy, 2013) quality of work life (QWL) is the level of organization that is able to satisfy the needs of members of the organization through experience in the organization. Suttle (1997) also emphasizes that QWL is the extent to which such work can be carried out to meet essential personal basic needs through their experience in the organization (Rethinam \& Ismail, 2008). QWL's goal is to enhance organizational effectiveness in opportunities for creativity, satisfaction and work and an effective working environment (Varghese \& Jayan, 2013

As a construct QWL cares for the well-being of employees, leads to job satisfaction as its outcome, and includes workplace effects on job satisfaction, satisfaction in the out-of-life area of life, and satisfaction with overall life, personal happiness and subjective well-being (Otto and Bourget , 2006, referring to Sirgy, Efraty, Siegel et al., 2001). Quality of Work Life is one effective tool to manage the interests of management and employee, to achieve the goals set by the organization, while protecting the rights and dignity of its employees.

The QWL Program aims to provide education, both for workers and for corporate leaders, to create harmonious relationships of all members of the organization. With the implementation of this program, then not only the management will be helped, but the employee will be benefited. With the fulfillment of employee needs, it is expected job satisfaction and employee productivity will also increase, which will ultimately impact on organizational productivity. In other words, this program will bridge the interests of both parties, namely the management and the employees. With the implementation of the program of QWL, the humanism will increasingly influence the organizational climate.

Employees with high QWL generally have a fairly comfortable life, assuming their work is an exciting job and achieving a level of personal satisfaction from the work done. In other words employees who are generally satisfied with their work are said to have a high QWL, and people who are not satisfied with their work are said to have a low 
QWL (Varghese \& Jayan, 2013). Employees with high QWL will have a positive impact on the company. Bharathi, Umaselvi \& Kumar, 2011 (in Varghese \& Jayan, 2013) says that QWL is one of the efforts to utilize the existing human assets within the organization. Good employee performance will have a positive impact in achieving organizational success.

The selected constructs of QWL that were used in this article are derived from the European Foundation for the Improvement of Living and Working Condition (EWON) (2002) who have used the dimensions widely in their QWL studies. These factors are believed to be appropriate and reliable in the context of Asia generally and Malaysia specifically because some of the factors were used separately by researchers in Japan (Fujigaki, Asakura and Haratani, 1993), Singapore (Lau et al., 2001) and Malaysia (Rethinam, Maimunah, Musa and Bahaman, 2004). The dimensions of QWL selected are health and well-being, job security, job satisfaction, competence development and the balance between work with non-work life.

Health and well-being of QWL refer to physical and psychological aspects of an individual in any working environment. Job security, the central aspect of QWL represents strength of the organizations to provide permanent and stable employment regardless of the changes in work environment. Job satisfaction is defined as an employee's level of positive effect towards job or job situation that enhances quality of work life. Career development opportunity will provide essential training that will help the individual employees to equip with the new skills to spearhead in their career. A major component of QWL, which is important for both the employees and the employers, is the relationship between work and home life. An ILO convention that was adopted in 1981, states that it is necessary for organizations to help employees to balance their work and non-work demands (Lewis, 1997).

\section{- Research methods}

Action research is a method designed to improve an implementation process and consists of action, evaluation, and critical reflection (Koshy, Koshy, \& Waterman, 2011). Arnold, Cooper and Robertson (2004, referring to Lewin, 1946) used the term to describe the action research study in which researchers and research subjects participating together. Action research is intended in addition to solving the problems facing the subject of research, as well as to increase knowledge about the topic being studied. This research not only diagnose and investigate a specific problem, but it also makes changes in the organization of work, based on research results, and evaluate the impact of these changes. Action research can use a variety of other research methods, but as a qualitative research, in general, the most widely used method are interview and participant observation. Furthermore, compared with other study design, this method is driven by specific problems that arise in the organization and the desire to solve them. Susman (1983) describes five steps in conducting action research, namely: identify the problem, to consider various alternatives related solutions to these problems, carry out actions solution, an evaluation related to the action solution that has been done, and the last step is to study about the success of the solution (in O'Brien, 1983).

Population in this research is all management staff and employees of head office that exist in X company. The company is one of the private companies engaged in manufacturing, especially in the field of building construction. Along with the high economic growth and rapid development of the construction sector, particularly infrastructure and property development, $\mathrm{X}$ company participates through the business of providing Ready Mix Concrete, Masonry Concrete and Machine Break / Base Coarse, as well as other building materials made from Raw cement. It has several branch offices in Gresik, Tuban, Solo, Makassar, Purwokerto, Yogyakarta, Pandaan, and Semarang. Increased development in several regions in Indonesia makes the employees of $\mathrm{X}$ company must work relative hard to follow the company's development wheel. The management sees every employee as an asset to his company. The management want to see more about the quality of working life owned by employees.

The research begins with pre-assessment stage in the form of giving Quality Work Life questionnaire to 115 employees to get information about the problems that exist in the organization where the research took place. The next step is to conduct interviews as an assessment stage to some employees of PT X, followed by FGD (Focus Group Discussion) to deepen and expand the information. Conclusions from the mapping of results from Focus Group Discussion using SWOT analysis (Strengths, Weaknesses, Opportunities, and Threats)

\section{- Intervention and Discussion}

Based on the data obtained from the assessment and SWOT analysis, some thoughtful programs will be designed to bring about changes in the organization. The programs that have been conducted on research for the first 2 years are as follows:

1. Design of Change Management Program to Improve Quality of Work Life.

Given the QWL program is a relatively new long-term program for the organization, it is necessary to have an atmosphere conducive to the changes. According to Schein (1996) one of the management action that can improve QWL is organizational development based on change management, i.e the process of planned change by the organization with specific directions and objectives (Cameron \& Green, 2009), the process for achieving the goals of change by planning and introducing systematically, and taking into account possible rejection (Armstrong, 2009). The concept used for organizational change is from Lewin (in Cameron \& Green, 2009; Dessler 200), which includes three steps: unfreeze, move, and refreeze. Based on the research, it can be known that the unfreeze stage of the change management process can realize the employees to do more and more employees are aware of the importance of QWL which will make it easier for companies to make 
changes and minimize the number of resistance. This unfreeze stage change is done by the whole organizational member. To introduce a relatively new concept for organizational members, it is necessary to build the readiness of all members of the organization, both management and employees. Overall, employees are keen to engage in a process of change and are willing to accept the offer of a new program, particularly those seen as promising to bring them to a better level of wellbeing, which is not limited to material but more integrative, balance of physical, psychological and mental life.

2. Building professionalism as an organizational culture through time management training and assertive communication as a means to support $Q W L$.

In relation to organizational culture that is more inclined towards the culture of the people (guyub), it is necessary to have a cultural shift that can support the implementation of long-term programs and can be effective to compete in the future, without removing the existing cultural. The pretest, posttest and follow up are given in the training. The intervention applied in this research is to build professionalism through training related to time management and assertive communication as a means to balance work and personal life. Commitment and support from management, especially top management (CEO) will greatly determine the success of the introduction and establishment of a new program.

3. Job Evaluation as a Step for Developing Financial Aspects of Reward Management System.

Companies with a good quality of work life will look more attractive to the workers to join or survive in an organization (Kanten \& Sadullah, 2012). One of the dimensions of QWL highlighted in this research is job satisfaction because both of these concepts have a strong correlation, which is 0.754 (Othman, \& Lieng, 2009). Job satisfaction perceived by employees should be one of the important considerations of the company because the high level of job satisfaction correlates closely with the commitment to the organization, the quality and quantity of work productivity (Ganguly, 2010; Celik, 2011; Chitra \& Mahalakshmi, 2012). Based on the results of initial assessment analysis related to job satisfaction and fairness, the factors that cause the low level of employee job satisfaction according to Herzberg's two factor theory or financial reward factor. Based on the results of interviews related to the payroll system, it is informed that during the payroll or reward system does not have a strong base of consideration so that sometimes the issue of unfairness comes out.

It is therefore necessary to improve and develop a reward system, to conduct further analysis and evaluation of the results of job evaluation, and to make a performance appraisal system for each holder of the position that is objective and systematic so that the results of the job evaluation can be applied in the pay structure more equitably and equally, because it has been in accordance with the performance of individual work. The proposed job grading design is expected to be an input in developing and updating the reward system applicable within the company. The new system should be followed by information of procedure and detail information so that there will be no misunderstanding within the employees.

4. Employee Assistance Program (EAP) Design to Support the Improvement of Quality of Work Life (QWL).

From the analysis of stress instrument data, it is obtained that there are areas that need to be considered by the company, namely role insufficiency , role ambiguity, role boundary, and vocational strain. These four aspects are the areas of stressors that occupy the highest place in the effective contribution to form stress. The first three aspects are areas of work-related problems and Vocational Strain is an area of attitudes toward work that contributes to stress in most of the respondent. In addition, there are four personal areas that become weaknesses, which are recreation, self care, social support, and rational / cognitive coping. Supposedly, the four areas were used as personal resources in overcoming the stressors that occurred, but the data showed that they were not good enough. The necessary coping can be curative or preventive. Curative because it is a fix and overcome the problem that is or has happened, while the preventive form of strengthening of personal resources that will be able to be an early intervention or filter against the symptoms of stress that appears. Education on self-empowerment will also help preventive measures for employees to prevent widespread stress and affect performance and other aspects of life. The Employee Assistance Program needs to be established to perform all of these actions. After mapping the issues to determine the direction of the services provided, then the standards and guidelines have been adapted from the EAPA Standard and Professional Guidelines for Employee Assistance Program.

5. Training and Development of Stress Management Model.

The results of the assessment identified four sources of stress that need to be considered: vocational strain, role insufficiency, role ambiguity, and role boundary as organizational factors and personal factors including recreation, self care, social support, and rational / cognitive coping aspects. The results of data analysis indicate that the factor of personal resources have been correlated to the emergence of stress derived from organizational factors. Based on the result of the research the stress management model was developed as preventive action which can be done by the management and employees. From the results of the training that has been done, it can be concluded that the participants feel satisfied and get new knowledge about coping stress. The feeling of satisfaction is a key factor for employees to be motivated in working. For the annual program it was suggested that several programs can be held such as Rational / Cognitive Coping (Cognitive Behavior Therapy Training, Gratitude Therapy, Assertive 
Training), Self Care (Personal Development Training, Self Management Training, regular exercise and humor therapy), and Social Support (interpersonal support training, character building training, social skills training and self-confidence training)

\section{- Recommendation}

1. Management can play a larger role in supporting the success of the QWL program, which is basically to promote joint prosperity, both for the employees and the management. In the next phase there is a need to establish a system that can maintain the sustainability of program implementation.

2. The management may also play a role in providing the necessary facilities and infrastructure in the implementation of the program or the establishment of a supportive system (such as performance appraisal, selection system, recruitment, and placement), as well as preparing competent human resources for it.

3. Socialization of programs and equal opportunity for all employees to understand and improve the quantity and quality of activities in a structured, planned, and integrated with organizational needs

4. Management can also carry out orientation activities for new employees to socialize the cultural values of the organization. The purpose of the implementation of orientation is as a medium of information for new employees to understand about the culture and goals of the organization. It can be their guide in behaving in the work environment so as to facilitate in achieving organizational goals.

\section{References}

[1] Ahmadi et.al. (2011). To the promotion of work life quality using the paradigm of managerial coaching: The role of managerial coaching on the quality of work life. Journal of Business Management Vol. 5(17), pp. 7440-7448, 4

[2] Armstrong, M. (2009). Armstrong's handbook of human resource management practice $11^{\text {th }}$ edition. London \& Philadelphia: Kogan Page.

[3] Auerbach, C. F. \& Silverstein, L. B. (2003). Qualitative data: An introduction to coding and analysis. USA: New York University Press.

[4] Azzone, V., et al. (2009). Workplace stress, organizational factors and EAP utilization. Journal of Workplace Behavioral Health, 24, 344-356.

[5] Bophela, N. R., \& Govender, P. (2015). Employee assistance programs (EAPs): tools for quality of work life. Problems and Perspectives in Management, 13(2).

[6] Burnes, B. (2004). Kurt Lewin and complexity theories: back to the future?. Joumal of Change Management, Vol. 4, No. 4, 309-325

[7] Cameron, E., \& Green, M. (2009). Making sense of change management, 3rd ed. Philadelphia: Kogan Page. ISBN: 978-0-7494-6435-6 (pbk).
[8] Carpita, M. \& Golia, S. (2012). Measuring the quality of wok: The case of the Italian social cooperatives. Qualitative Quantitatve, 46, 1659-1685.

[9] Cascio, W. F. (1999). (4 ${ }^{\text {th }}$ Ed). Costing human resources: The financial impact of behavior in organization. Ohio: Thomson Rights.

[10] Celik, M. (2011). A theoretical approach to the job satisfaction. Polish Journal of Management Studies, 4, 7-15.

[11] Chitra, D. \& Mahalaskhmi, V. (2012). A study on employees' perception on quality of work life and job satisfaction in manufacturing organization: An empirical study. International Journal of Trade and Commerce, 1(2), 175-184..

[12] Cooper, Cary L. \& Ivan T. Robertson.(2004). Work Psychology: Understanding Human Behaviour in The Workplace . $4^{\text {th }}$ ed. Prentice Hall

[13] Cumming, T.G., \& Worley, C.G. (2009). Organizational Development \& Change. Canada: South Western Cengage Learning.

[14] Curtis, D.F., \& Kelly, L.L. (2012). Effect of a quality of life coaching intervention on psychological courage and self-determination. International Journal of Evidence Based Coaching and Mentoring. (11)1. 2038

[15] DeCenzo, D., \& Robbins, S. (2008). Fundamentals Of Management: Essential Concepts and Applications 6th Edition. Upper Saddle River, New Jersey : Pearson Prentice Hall.

[16] DeCenzo, D. \& Robbins, S. (2010). Fundamental of human resource management 10th edition. United States of America: John Willey \& Sons Inc.

[17] Dessler, G. (2008). Human Resource Management, 11 th edition. New Jersey: Pearson Prentice Hall.

[18] EAPA (2010). EAPA Standards and Professional Guidelines For Employee Asisstance Programs. Diunduh dari http://www.eapassn.org/Portals/11/Docs/EAPAStanda rds10.pdf

[19] El-Hajji, M. A. (2011). Wage consistency in the context of job evaluation: An analytical view. International Journal of Business and Social Science, 2(10), 31-37.

[20] Employee Assistance Programs - Philosophy, theory and practice. (1986). Royal Canadian Mounted Police External Review Committee.

[21] Fujigaki, Y., T., Asakura, and T., Haratani (1994). Work Stress and Depressive Symptoms Among Japanese Information Systems Managers. Industrial Health, 32(4), pp. 231-238.

[22] Ganguly, R. (2010). Quality of worklife and job satisfaction of a group of university employees. Asian Journal of Management Research, 209-216.

[23] Green, M. (2007). Change management masterclass : a step by step guide to successful change management. Philadelphia: Kogan-Page.

[24] Greenhaus, J.H., Collins, K.M. \& Shaw, J.D. (2003). The relation between work-family balance and quality of life. Journal of Vocational Behavior, vol. 63, pp. 510-31. 
[25] Heskett, J.L., Sasser, W.E., Jr and L.A., Schlesinger (1997). The Service Profit Chain. New York : The Free Press

[26] Islam, Zohurul and Sununta Siengthai. (2009). Quality of Work Life and Organizational Performance : Empirical Evidence from Dhaka Export Processing Zone.

Https://www.researchgate.net/publication/254415281.

[27] Kanten, S., \& Sadullah, O. (2012). An empirical research on relationship quality of work life and work engagement. Procedia - Social and Behavioral Sciences.62 ( 2012 ) 360 - 366

[28] Lau, T., Y.H., Wong, K.F., Chan, and M. Law (2001). Information Technology and the Work EnvironmentDoes it Change the Way People Interact at Work. Human Systems Management, 20(3), pp. 267-280

[29] Lawler, F. 1982. Strategies for Improving the Quality of Work Life. American Psychologist. 37 : 486-49

[30] Lewis, S. (1997). An International Perspectives on Work-Family Issues. In S. Parasuraman and J.H. Greenhaus eds. Integrating Work and Family : Challenges and Choises for a Changing World. Westport, CN :Quorum Books.

[31] Li, J., \& Yeo, R. K. (2013). In pursuit of learning: sensemaking the quality of work life. European Journal of Training and Development, 37(2), 136-160. doi: 10.1108/03090591311301662

[32] Milkovich, G. T., \& Newman, J, M. (2008). Compensation $9^{\text {th }}$ edition. Singapore: McGraw-Hill Companies Inc.

[33] Othman, A., \& Lieng, M. C. (2009). Relationship between quality of work life (QWL) and job satisfation: a case study of enterprise "XYZ" in Malacca. International Conference on Human Capital Development, Pahang, 25-27 May.

[34] Ouppara, N.S., \& Victoria, U. (2012). Quality of Work Life Practices in a Multinational Company in Sydney,Australia. Procedia - Social and Behavioral Sciences (40).116-121

[35] Paton, R.A., \& McCalman, J. Change Management: A Guide to Effective Implementation, 3rd ed. London: Sage. ISBN: 978-1-4129-1221-1(pbk).

[36] Pieterse, J.H., Caniëls, M.C.J., \& Homan, T. (2012), Professional discourses and resistance to change, Journal of Organizational Change Management, Vol. 25 Iss: 6 pp. 798 - 818

[37] Reilly, N.P., Sirgy, M.J., Gorman, C.A. (2012). Work and Quality of Life: Ethical Practices in Organizations. NY: Springer.

[38] Rethinam, G.S., \& Ismail, M. (2008). Constructs of Quality of Work Life: A perspective of information and technology professionals. European Journal of Social Sicence, 7(1), 58-70.

[39] Royuela, V., Lopez-Tamayo, J., \& Surinach, J. (2007). The institutional vs. the academic definition of the quality of work life. What is the focus of the European Commission?. Social Indicators Researchs, 86, 401415.

[40] Sail, J. \& Pawar, P. (2013). A Study on Performance Management and Worklife Balance of Corporate Working Women. International Monthly Refereed
Journal of Research In Management \& Technology . Volume II -ISSN - 2320-0073.

[41] Sarayreh, B.H., Khudair, H. \& Barakat, E.A. (2013). Comparative Study: The Kurt Lewin of Change Management. International Journal of Computer and Information Technology, Volume (02)04 -ISSN: 2279 $-0764$

[42] Schermerhorn (2008). Management, 9th. United States: Wiley

[43] Secapramana, Verina H. (2015). Employee Assistance Program as An Intervention to Improve The Quality of Work Life. Fakultas Psikologi Universitas Surabaya.

[44] Sirgy, M. J., Reilly, N. P., Wu, J., \& Efraty, D. (2008). A Work-Life Identity Model of Well-Being: Towards a Research Agenda Linking Quality-of-Work-Life (QWL) Programs with Quality of Life (QOL). Applied Research in Quality of Life, 3(3), 181-202. doi: 10.1007/s11482-008-9054-6

[45] Varghese, S., \& Jayan, C. (2011). Quality of Work Life: A Dynamic Multidimensional Construct at Work Place - Part I. Guru Journal of Behavioral and Social Sciences, 1(1). ISSN: 2320-9038

[46] Venkatesh, J., \& Aarthy, C. (2013). Assessment and Evaluation of Producing Efficiencies in Textile Industry through Quality of Work Life. Autex Research Journal, 13(4). doi: 10.2478/v10304-0120042-4

[47] Ventegodt, S. \& Merrick, J. (2009). Health and Happiness from Meaningful Work: Research in Quality of Working Life. New York: Nova Science Publisher Inc. 
Table 1.1. Pre-Assessment Result

\begin{tabular}{|c|c|c|c|c|c|c|c|c|c|c|}
\hline Aspek & SR & $\%$ & $\mathbf{R}$ & $\%$ & $\mathbf{C}$ & $\%$ & $\mathbf{T}$ & $\%$ & ST & $\%$ \\
\hline Health and well being & 13 & 11,3 & 25 & 21,7 & 29 & 25,2 & 15 & 13 & 33 & 28,6 \\
\hline Job Security & 4 & 3,5 & 1 & 0,8 & 32 & 27,8 & 47 & 40,8 & 31 & 26,9 \\
\hline Job Satisfaction & 19 & 16,5 & 25 & 21,7 & 29 & 25,2 & 18 & 15,6 & 24 & 20,8 \\
\hline Competence Development & 1 & 0,8 & 3 & 2,6 & 2 & 1,7 & 16 & 13,9 & 93 & 80,8 \\
\hline Work and Non Work Life Balance & 23 & 20 & 19 & 16,5 & 32 & 27,8 & 18 & 15,6 & 23 & 20 \\
\hline
\end{tabular}

Table 1.2. SWOT Analysis Result

\begin{tabular}{|c|c|c|}
\hline \multicolumn{2}{|r|}{ Strengths } & Weaknesses \\
\hline 1. & $\begin{array}{l}\text { There is awareness } \\
\text { in the employees to } \\
\text { be responsible for } \\
\text { the whole process of } \\
\text { work in the } \\
\text { company }\end{array}$ & $\begin{array}{l}\text { A person's attitude } \\
\text { negatively affects the } \\
\text { formation of } \\
\text { professionalism in } \\
\text { employees and } \\
\text { management. }\end{array}$ \\
\hline 2. & $\begin{array}{l}\text { Guyub atmosphere } \\
\text { and kinship are very } \\
\text { strong in the } \\
\text { company so that the }\end{array}$ & $\begin{array}{l}\text { 2. There is disharmony in } \\
\text { some employees that } \\
\text { affect their work style. }\end{array}$ \\
\hline 3. & $\begin{array}{l}\text { sense of belonging } \\
\text { is arisen } \\
\text { There is awareness } \\
\text { in the employees to } \\
\text { improve }\end{array}$ & $\begin{array}{l}\text { 3. Some employees are } \\
\text { having trouble in having } \\
\text { understanding from the } \\
\text { family due to the work } \\
\text { load }\end{array}$ \\
\hline 4. & $\begin{array}{l}\text { competencies } \\
\text { Employee } \\
\text { awareness of the } \\
\text { importance of fair } \\
\text { and transparent } \\
\text { recruitment. }\end{array}$ & $\begin{array}{l}\text { 4. Unmet facilities, both } \\
\text { physically and } \\
\text { psychologically, hindering } \\
\text { the development of the } \\
\text { organization. }\end{array}$ \\
\hline 5. & $\begin{array}{l}\text { The desire of } \\
\text { employees to } \\
\text { participate in }\end{array}$ & $\begin{array}{l}\text { 5. Lack of clear parameters } \\
\text { regarding performance } \\
\text { appraisal. }\end{array}$ \\
\hline 6. & $\begin{array}{l}\text { 1mproving and } \\
\text { developing the } \\
\text { company by } \\
\text { contributing ideas } \\
\text { The awareness of } \\
\text { the company to }\end{array}$ & $\begin{array}{l}\text { Lack of fairness in terms } \\
\text { of bonus distribution, } \\
\text { implementation of rules, } \\
\text { recruitment, and } \\
\text { promotion of employees. }\end{array}$ \\
\hline 7. & $\begin{array}{l}\text { improve the quality } \\
\text { of working life of } \\
\text { employees. } \\
\text { Existence of } \\
\text { prooram from }\end{array}$ & $\begin{array}{l}\text { 7. Sometimes the results of } \\
\text { the training they follow } \\
\text { are not applied in real } \\
\text { terms. }\end{array}$ \\
\hline 8. & $\begin{array}{l}\text { company to } \\
\text { improve } \\
\text { performance } \\
\text { appraisal system. } \\
\text { The company has a }\end{array}$ & $\begin{array}{l}\text { Some employees are not } \\
\text { concern about the quality } \\
\text { of work life; they are more } \\
\text { focused on the job itself } \\
\text { without having job }\end{array}$ \\
\hline
\end{tabular}

training \&

assessment center to improve hard skill and soft skill competency of employees. satisfaction.

9. The existence of employees who are resistant to change, make it difficult to adjust to the system and to the new company policy.

10. 10. There is difficulty in some employees in managing the emotions when having problems at work or personal life. 